\title{
Statyba
}

\section{HIGHER ORDER INTEGRATION METHODS FOR STRUCTURAL DYNAMICS PROBLEMS}

\section{R. Baušys}

To cite this article: R. Baušys (1996) HIGHER ORDER INTEGRATION

METHODS FOR STRUCTURAL DYNAMICS PROBLEMS, Statyba, 2:7, 6-12, DOI:

10.1080/13921525.1996.10531649

To link to this article: https://doi.org/10.1080/13921525.1996.10531649

曲 Published online: 26 Jul 2012.

Submit your article to this journal $\pi$

III Article views: 164 


\title{
HIGHER ORDER INTEGRATION METHODS FOR STRUCTURAL DYNAMICS PROBLEMS
}

\author{
R.Baušys
}

\section{Introduction}

Direct time-integration methods for structural dynamics problems have long been a subject of various investigations. Most finite element techniques for the solution of structural dynamics problems are traditionally based on semidiscretisations: finite element approach is used only for spatial domain to reduce the partial differential equations to a system of second order ordinary differential equations in time. Then, the semidiscrete equations are further solved using mode superposition method or the step-by-step direct time integration methods. Most commonly used algorithms of direct integration for transient analysis are based on the traditional finite difference methods $[1,2]$. Alternatively, the finite element method has come to be recognized as powerful tool for structural dynamics problems $[3,4]$. The underlying concept of their formulations is that , using continuous functions in time, the ordinary differential equations emanating from semi-discretisations are multiplied by weighting functions and integrated over time intervals. Many traditional direct time integration algorithms were rederived in this manner.

Another approach, working from the viewpoint of the solution of the differential equations, has evolved during the last two decades. The main idea is to permit the unknown parameters to be discontinuous at the discrete time levels. The timediscontinuous Galerkin (DG) method was originally developed for solution of scalar linear hyperbolic equations [5]. Since then, it has been successfully applied to second order hyperbolic problems [6] and the solution first order ordinary differential equations [7]. It has been shown that DG method possesses properties not present in the traditional semi-discrete algorithms. In particular, it leads to Astable, higher order accurate solution procedures for ordinary differential equations and provides a new possibilities for the development of adaptive strategies. This is in contrast to the conditional stability of some time-continuous Galerkin methods [4]. Much research was conducted by Hulbert [8] to apply time discontinuous Galerkin methods to computational structural dynamics. While stability is easily proved for this method, convergence has been proved only for $P^{1}$ polynomials, that is for linear elements in time. So Hulbert [8] proposed timediscontinuous Galerkin/least squares approach to circumvent this limitation. From a computational view point, the additional least squares terms destroy the banded structure of the matrices and cost of the solution of structural dynamics problems increase compared with the original DG time finite element method.

The proposed DG scheme is constructed using weighting exponential function for the inner product introduced by French [9] for space-time finite element method for second order hyperbolic problems. This weighting function is used when the basis functions of temporal domain have degree two or higher. The proposed time finite element strategy enables us to overcome aforementioned disadvantage of Galerkin /east squares approach, the case when the least squares terms destroy the banded structure of the system of equations.

We will consider a system of the ordinary differential equations associated with the semidiscrete form of linear elastodynamics 


$$
[M] \ddot{u}+[C] \dot{u}+[K] \boldsymbol{u}=F(t), \quad t \in(0, T)
$$

with the initial conditions

$$
\boldsymbol{u}(0)=U_{0}, \quad \dot{u}(0)=\dot{U}_{0}
$$

where $[M],[C]$ and $[K]$ are the mass, damping and stiffness matrices, respectively; $\boldsymbol{F}(t)$ is the prescribed vector of external load and $u$ is the vector of unknown nodal displacements. A superposed dot denotes differentiation in respect to time. [M] is assumed to be symmetric positive-definite while $[C]$ and $[K]$ are assumed to be symmetric positive semidefinite.

\section{Variational equation}

In order to define the DG method, we consider sequence of discrete time level $t_{n}\left(0=t_{0}<t_{1}<\ldots \ldots<t_{n}=T\right) \quad$ with the corresponding time steps $\Delta t_{n}=t_{n}-t_{n-1}$. We assume the function $v(t)$ to be discontinuous at time $t_{n}$, the temporal jump operator is defined by

$$
\left[v_{n}\right]=v_{n}^{+}-v_{n}^{-}
$$

where

$$
\begin{aligned}
& v_{n}^{+}=\lim _{s \rightarrow 0^{+}}\left(\boldsymbol{v}\left(t_{n}+s\right)\right) \\
& \boldsymbol{v}_{n}^{-}=\lim _{s \rightarrow 0^{-}}\left(\boldsymbol{v}\left(t_{n}-s\right)\right)
\end{aligned}
$$

The weight function is defined by

$$
\mu_{n}(t)=e^{-\alpha\left(t-t_{n-1}\right)}, \quad \alpha \geq 0
$$

For the sake of simplicity, the inner products can be expressed by

$$
\left.(v, u)_{I_{n}}=\int_{I_{n}} v u d t, \quad I_{n}=\right] t_{n-1}, t_{n} \mid
$$

The finite dimensional space of the interpolation functions for trial displacements can be presented as follows

$$
v=\left\{u \in \bigcup_{n=1}^{N}\left(\mathcal{P}^{k}\left(I_{n}\right)\right)\right\}
$$

By the construction, the interpolation functions are continuous within each time interval and can be discontinuous across the time intervals. Since the initial conditions are weakly enforced, the displacement weighting function space is identical to the trial displacement space.

The formulation of the proposed timediscontinuous Galerkin approach is:

Find $u \in v$ such that $\forall v \in v$,

$$
A(\boldsymbol{u}, \boldsymbol{v})_{n}=L(\boldsymbol{v})_{n}, n=1,2 \ldots \ldots \ldots . . N
$$

where

$$
\begin{aligned}
A(u, v)_{n} & =\left(\dot{v} \mu_{n}, L u\right)_{I_{n}} \\
& +\dot{v}_{n-1}^{+}[M] \dot{u}_{n-1}^{+}+v_{n-1}^{+}[K] u_{n-1}^{+} \\
L(v)_{n} & =\left(\dot{v} \mu_{n}, F\right)_{I_{n}} \\
& +\dot{v}_{n-1}^{+}[M] \dot{u}_{n-1}^{-}+v_{n-1}^{+}[K] u_{n-1}^{-} \\
n & =2, \ldots \ldots . . . N \\
L(v)_{1} & =\left(\dot{v} \mu_{n}, F\right)_{I_{1}} \\
& +\dot{v}_{0}^{+}[M] \dot{U}_{0}+v_{0}^{+}[K] U_{0}
\end{aligned}
$$

and

$$
\mathcal{L} u=[M] \ddot{u}+[C] \dot{u}+[K] u
$$

Note $L(v)_{1}$ is defined from the general expression $L(v)_{n}$ by replacing $\ddot{\boldsymbol{u}}_{n-1}$ and $\boldsymbol{u}_{n-1}^{-}$by the initial conditions $\dot{U}_{0}$ and $U_{0}$, respectively. The last two terms of (10), in combination with the last two terms of (11), weakly enforce the initial conditions for each time interval. These jump terms are stabilizing operators of proposed DG method. Problem (9) leads to a system of the linear equations with square coefficient matrix since $u$ and $v$ belong to the same finite dimensional space. 


\section{Hierarchical family of algorithms}

This time-discontinuous Galerkin approach enables us to construct a family of the algorithms for direct time integration. The main feature of this family is that the algorithms have a hierarchical structure. This means that the system of equations of a particular order contains as a subset the equations of all methods of lower order or in other words, the increased accuracy by this approach is obtained by adding one or more terms in the interpolation function, without modification of the previous ones. This is in contrast to traditional single-step integration methods, where increased accuracy may be obtained by reducing the time step length or by a change of integration methods, in this case a completely new system of equations has to be established and solved. Design of the hierarchical family of algorithms is based on single-field formulation of time finite element approach. Using typical finite element procedure, the basis interpolation functions are defined in terms of Lagrange polynomials, a $k$-th order polynomial in time may be expressed in terms of nodal values at $k+1$ time levels. Alternatively, a $k$-th order polynomial may be constructed from $k+1$ terms of a Taylor series expansion in time. Linear in time interpolation of the displacement can be written as

$$
u^{h}(t)=u_{n-1}^{+}+\left(t-t_{n-1}\right) v_{n}, t \in I_{n}
$$

The constant in time value $u_{n-1}^{+}$defines the displacement at the beginning of the $n$-th time interval, $v_{n}$ is the constant velocity in the time interval. In the same way, quadratic interpolation function of displacement may be constructed as follows

$$
u^{h}(t)=u_{n-1}^{+}+\left(t-t_{n-1}\right) v_{n-1}^{+}+\frac{1}{2}\left(t-t_{n-1}\right)^{2} a_{n}
$$

where $v_{n-1}^{+}$defines the velocity at the beginning of the time interval, $a_{n}$ is the constant acceleration. In this case, velocity varies linearly and is calculated using

$$
v^{h}(t)=v_{n-1}^{+}+\left(t-t_{n-1}\right) a_{n}
$$

These expansions are used in variational formulation for the trial displacements and weighting functions in (9). Displacements, velocities and accelerations are then obtained by solving the resultant system of equations. Substitution of the linear interpolation function for displacements (14) into (9) yields

$\left[\begin{array}{cc}{[K]} & 0 \\ b_{1}[K] & {[M]+b_{1}[C]+b_{2}[C]}\end{array}\right]\left\{\begin{array}{c}u_{n-1}^{+} \\ v_{n}\end{array}\right\}=\left\{\begin{array}{c}{[K] u_{n-1}^{-}} \\ {[M] v_{n}+F_{1 n}}\end{array}\right\}$

where the coefficients $b_{1}, b_{2}$ and $F_{1 n}$ are defined as follows

$$
b_{1}=\frac{1-e^{-\alpha N}}{\alpha}
$$

$$
b_{2}=\frac{1-e^{-\alpha \Delta t}(\alpha \Delta t+1)}{\alpha^{2}}
$$

$$
\left.F_{l n}=\int_{I_{n}} \mu F d t, \quad I_{n}=\right] t_{n-1}, t_{n}[
$$

The system of equations obtained from (9) using quadratic interpolation function for displacements can be expressed as

$$
\left[\begin{array}{ccc}
{[K]} & 0 & 0 \\
b_{1}[K] & {[M]+b_{1}[C]+b_{2}[K]} & b_{1}[M]+b_{2}[C]+\frac{1}{2} b_{3}[K] \\
b_{2}[K] & b_{2}[C]+b_{3}[K] & b_{2}[M]+b_{3}[C]+\frac{1}{2} b_{4}[K]
\end{array}\right]\left\{\begin{array}{c}
u_{n-1}^{+} \\
v_{n-1}^{+} \\
a_{n}
\end{array}\right\}=\left\{\begin{array}{c}
{[K] u_{*-1}^{-}} \\
{[M] v_{n-1}^{-}+F_{1 n}} \\
F_{2 n}
\end{array}\right\}
$$


where $v_{n-1}^{-}$is the velocity at the end of the previous $(n-1)$-th interval and the values of the coefficients $b_{1}$ and $b_{2}$ can be written as

$$
\begin{aligned}
& b_{3}=\frac{2-e^{-\alpha \Delta t}\left(\alpha^{2} \Delta t^{2}+2 \alpha \Delta t+2\right)}{\alpha^{3}} \\
& b_{4}=\frac{6-e^{-\alpha \Delta t}\left(\alpha^{3} \Delta t^{3}+3 \alpha^{2} \Delta t^{2}+6 \alpha \Delta t+6\right)}{\alpha^{4}} \\
& \left.F_{2 n}=\int_{\mu} F\left(t-t_{n-1}\right) d t, I_{n}=\right] t_{n-1}, t_{n}
\end{aligned}
$$

It is not difficult to observe that the higher order interpolation functions of time finite elements provide hierarchical structure of the governing equations. It follows that the matrix in (17) corresponding to the linear in time interpolation of the displacement is a submatrix of the matrix in (21) corresponding to a quadratic in time interpolation of the displacement. In relation to advantage we can say that the hierarchical formulation is optimal because it allows for all information to be passed from one discretisation level to the second discretisation level and enables a convenient design of predictormulticorrector algorithms which retain the stability in all phases of the numerical procedure.

\section{Stability and error analysis}

Since any $n$ degrees of freedom coupled system can be decomposed into $n$ uncoupled scalar equations, it can be established that the entire coupled system reduces to consideration of the individual model equation [10]. Thus the analysis is performed on the scalar single degree of freedom harmonic oscillator model problem with no damping or friction

$$
\ddot{d}+\left(\omega^{h}\right)^{2} d=0
$$

with

$$
d(0)=d_{0} \quad \text { and } \dot{d}(0)=v_{0}
$$

where $\omega^{h}$ is the natural frequency of the system and $d$ is the magnitude of the displacement.

In the present analysis a particular emphasis is placed on the dissipative properties and the temporal accuracy of the proposed family of algorithms.

For the purposes of analysis, it is useful to transform each of the numerical formulations to the discrete form, that is to express the values at the end of the time interval ( $u_{n}^{-}$and $\left.\dot{u}_{n}^{-}\right)$in terms of the values at the end of the previous time interval. This can be written in the form

$$
\left\{\begin{array}{c}
u_{n}^{-} \\
\Delta t \dot{u}_{n}^{-}
\end{array}\right\}=[A]\left\{\begin{array}{c}
u_{n-1}^{-} \\
\Delta t \dot{u}_{n-1}^{-}
\end{array}\right\}
$$

where $[A]$ is the numerical amplification matrix.

Convergence of a numerical formulation requires consistency and stability. Consistency can be determined from the truncation error. Stability is determined by spectral radius of the numerical amplification matrix which is defined by

$$
\rho([A])=\max _{i}\left|\lambda_{i}([A]), i=1,2, \ldots, N\right|
$$

where $N$ is the dimension of the amplification matrix.

The formulation is unconditionally stable if the spectral radius is less than or equal to unity, i.e.

$$
\rho([A]) \leq 1
$$

Fig. 1 depicts spectral radii for the timediscontinuous Galerkin method obtained using the different interpolations. Also it is shown spectral radius for the Galerkin/least squares approach using quadratic interpolation function developed by Hulbert [8]. The following notation is adopted: Galerkin/least squares method -(GLS), the present approach with linear -(DGLL), with quadratic (DGLQ) and with cubic -(DGLC) interpolations of the displacement. Differences between numerical formulations using linear and quadratic or cubic interpolation functions may be easily observed in the low frequency region. The numerical formulations based on quadratic and cubic interpolation functions provide very close results. 


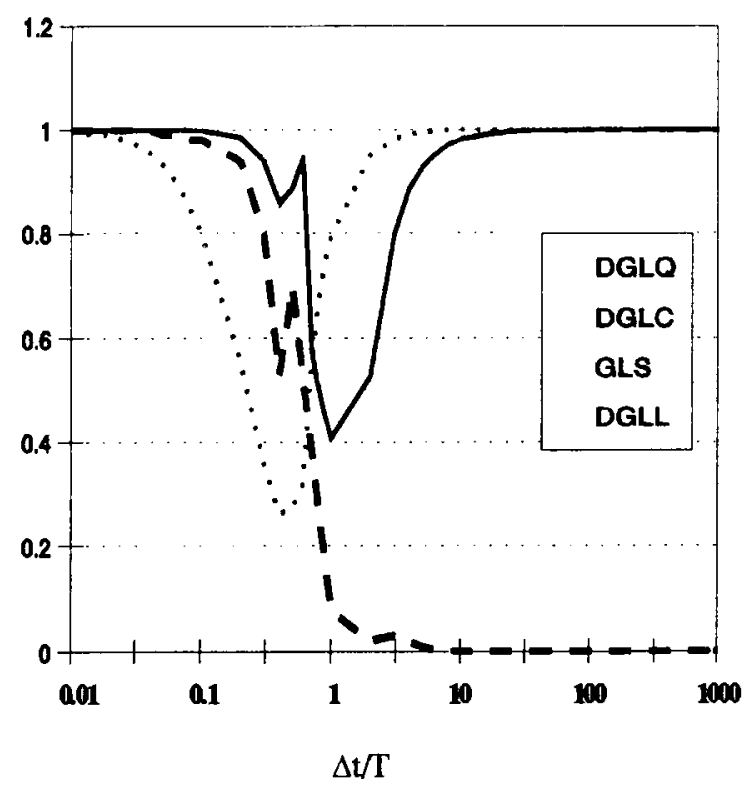

Fig.1. Spectral radii for Galerkin/least squares and the proposed approach

When solving dynamical problems it is common procedure to separate the error in numerical schemes, into dissipation, namely, amplitude error, and dispersion, namely, phase error. Provided that the eigenvalues of $[A]$ remain complex $\left(\lambda_{1,2}([A])=A \pm i B, B \neq 0\right)$, algorithmic damping ratio provides a measure of the numerical dissipation and can be expressed

$$
\bar{\xi}^{h}=-\frac{\ln \rho}{\Delta \omega^{-h}}
$$

Fig. 2 depicts algorithmic damping ratios of Galerkin/least squares and the different numerical formulations of the present approach. The same notation is adopted as in the previous figure. The numerical formulation based on linear interpolation function (DGLL) is clearly too dissipative to be of practical interest. It is observed that quadratic (DGLQ) and cubic (DGLC) interpolation functions for the proposed time-discontinuous Galerkin method provide less dissipation than Galerkin/least squares approach. It is important to recall that these formulations (DGLQ and DGLC) have very little dissipation in the low frequency domain.

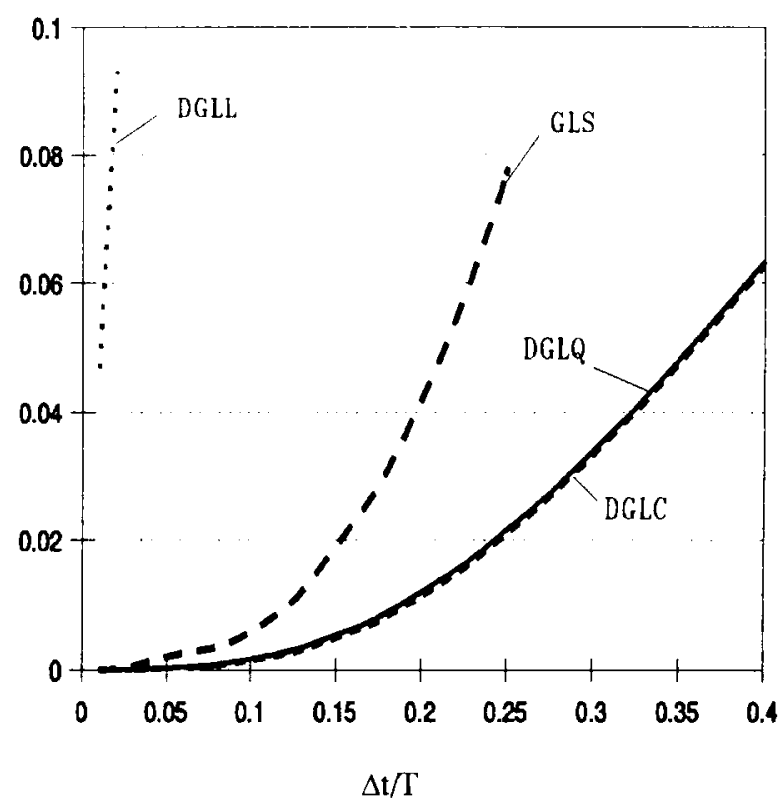

Fig. 2. Algorithmic damping ratios for time element methods

Dispersion in waves is generated when the phase velocity is a function of the frequency. The physical measure of the dispersion in one dimension (time), is the difference between analytical natural frequency and the numerical frequency. The relative frequency error provides a measure of the numerical dispersion and in the numerical expression it is given by

$$
\frac{\omega^{h}}{\omega^{h}}-1, \text { where } \bar{\omega}^{h}=\Delta t^{-1} \tan ^{-1}\left(\frac{B}{A}\right)
$$

Relative frequency error in the low frequency domain is shown in Fig. 3 for Galerkin/least squares, present time-discontinuous Galerkin with the different interpolation functions and trapezoidal rule (Newmark) algorithms. It is proved that, for unconditionally stable linear multistep methods, the trapezoidal rule algorithm provides the smallest error in frequency [11]. Time-discontinuous Galerkin and Galerkin/least squares formulations do not result in linear multistep approaches and thus can generate unconditionally stable algorithms which have less dispersion than the trapezoidal rule. The results shown in Fig. 3 demonstrate smaller relative frequency errors of the quadratic and cubic formulations. 


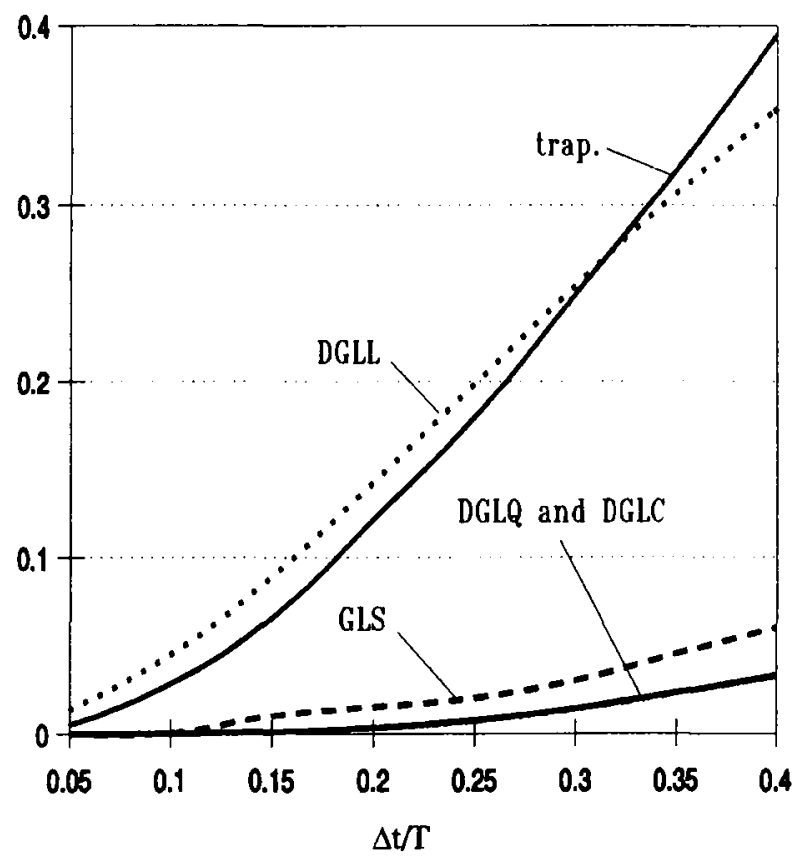

Fig. 3. Relative frequency errors for time element methods

To establish the results of the global truncation error, a posteriori convergence rate in \|\|$_{l}$ norm is evaluated, where the error is defined by

$$
\|\|_{1}=\int_{0}^{T} a b s(U-u) d t
$$

where $U$ and $u$ are the exact and approximate solutions respectively.

The results of rate of convergence obtained using different numerical formulations are shown in Fig. 4. The numerical procedure with linear interpolation function exhibits $O(\Delta t)$ order of accuracy, quadratic formulation $-O\left(\Delta z^{3}\right)$ and cubic formulation - $O\left(\Delta \varepsilon^{4.5}\right)$.

\section{Conclusions}

Time finite element method for solving second order ordinary differential equations associated with structural dynamics is presented. The proposed approach is based on time-discontinuous Galerkin method. All formulations were characterized by the stability condition phase, dissipation and frequency errors, a posteriori convergence rate.

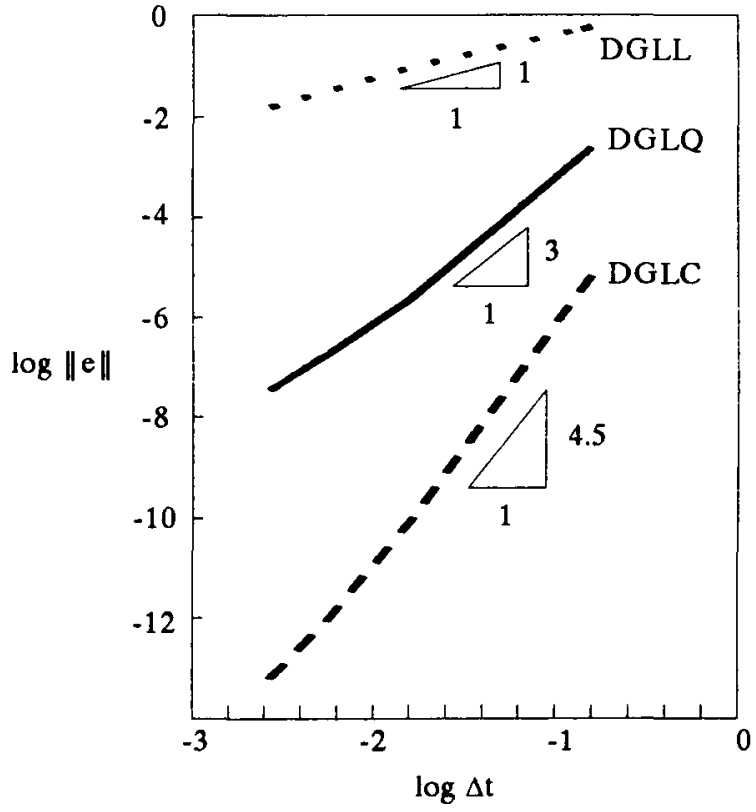

Fig. 4. A posteriori rate of convergence by different numerical formulations

\section{References}

1. M.A.Dokainish and K.Subbaraj. A Survey of Direct Time-Integration Methods in Computational Structural Dynamics-I. Explicit Methods // Comput. \& Struct., 32, 1989, p. 1371-1386.

2. M.A.Dokainish and K.Subbaraj. A Survey of Direct Time-Integration Methods in Computational Structural Dynamics-II. Implicit Methods // Comput. \& Struct., 32, 1989, p. 1387-1401.

3. J.H.Argyris and D.W.Scharpf. Finite Elements in Time and Space // Nucl. Eng. Des., 10, 1969, p. 456-464.

4. O.C.Zienkiewicz, W.L.Wood, N.W.Hine and R.L.Taylor. A Unified Set of Single Step Algorithms // Int. J. Numer. Methods Eng., 20, 1984, p. 1529-1552.

5. P.Lesiant and P.-A.Raviart. On a Finite Element Method for Solving Neutron Transport Equation // C. de Boor (ed.), Mathematical Aspects of Finite Elements in Partial Differential Equations, Academic Press, New York, 1974, p. 89-123.

6. C.Johnson. Discontinuous Galerkin Finite Element Methods for Second Order Hyperbolic Problems // Methods Appl. Mech. Eng., 107, 1993, p. 117-129.

7. M.Delfour, W.Hager and F.Trochu. Discontinuous Galerkin Methods for ordinary differential equations // Math. of Comput., 36, 1981, p. 455-473.

8. G.M.Hulbert. Time Finite Element Methods for Structural Dynamics // Int. J. Numer. Methods Eng., 33, 1992, p. 307-331. 
9. D.A.French. A Space-Time Finite Element Method for the Wave Equation // Comput. Methods Appl. Mech. Eng., 107, 1993, p. 145-157.

10.T.J.R.Hughes. The Finite Element Method, Linear Static and Dynamic Finite Element Analysis. NJ: Prentice-Hall, Englewood Cliffs, 1987.789 p.

11. G. Dahlquist. A Special Stabitity Problem for Linear Multistep Methods //. BIT, 3, 1963, p. 27-43.

Iteikta 19960626

AUKŠTESNĖS EILÉS INTEGRAVIMO METODAI
STRUKTŨRINES DINAMIKOS UŽDAVINIAMS
SPRĘSTI

R. Baušys

\section{Santrauka}

Laiko baigtiniu elementy metodai leidžia sudaryti efektyvius struktūrinès dinamikos uždavinių sprendimo algoritmus. Ju variacinès formuluotès sudaromos panaudojant tolydines laiko funkcijas. Paprastosios diferencialinès lygtys, gautos po diskretizacijos erdveje, yra padauginamos iš svorio funkciju ir integruojamos laiko intervaluose.

Pastaruoju metu plačiai tyrinètas trūkus laike Galiorkino metodas, sukurtas remiantis diferencialiniy lygčių sprendimo teorija. Jo pagrindinè ideja yra ta, kad diskretiniais laiko momentais ieškomieji parametrai gali būti trūkūs. Trūkio operatorius pateiktas lygtyje (3). Svorio funkcija aprašoma lygtimi (6). Trūkaus laike Galiorkino metodo, skirto struktūrinès dinamikos uždavinių sprendimui, variacinè formuluotè yra pateikta lygtyse (913). Si formuluotè igalina sukurti hierarchinę algoritmy šeimą, panaudojant skirtingos eilès laiko interpoliacines funkcijas. Lygčiu sistema, gauta panaudojant tiesines laiko interpoliacines funkcijas, yra pateikta lygtyje (17). Kvadratinés laiko interpoliacinès funkcijos sukuria lygciy sistemą (21). Aukštesnès eilès laiko interpoliacinès funkcijos sukuria hierarchinę lygčiu sistemos struktürą. Lyčiy sistemos (17) koeficienty matrica, atitinkanti tiesines laiko interpoliacines funkcijas, yra lygxių sistemos (21), atitinkancios kvadratines laiko interpoliacines funkcijas, koeficienty submatrica. Pagrindinès algoritmy̨ šeimos charakteristikos nustatomos klasikiniais modalinès analizès būdais. Pateikiami gauty charakteristikų palyginimai su kitais metodais.

Romualdas BAUŠYS. Doctor, Associate Professor. VGTU, Department of Engineering Mechanics. 11 Saulètekio Ave, 2054 Vilnius, Lithuania.

R.Bausys started to work at Vilnius Technical University in 1982. In 1989 he defended his doctoral thesis. R.Bausys is doing common research work with scientists from Chalmers University of Technology (Göteborg, Sweden). He has studied optimization and analysis procedures for non-linear problems. Nowadays R.Baušys is interested in the problems of error estimation and adaptive finite element strategies in statics and dynamics. 